\title{
Preparation of MgAl LDHs Intercalated with Amines and Effect on Thermal Behavior for Poly(vinyl chloride)
}

\author{
Xiaoyu Xue*, Hongmei Zhang, Shuhua Zhang* \\ College of Chemistry and Chemical Engineering, Shanghai University of Engineering Science, Shanghai, China \\ Email: 635749308@qq.com, ${ }^{*}$ shuhuazhang@lbl.gov
}

Received 27 September 2014; revised 14 November 2014; accepted 30 November 2014

Copyright $@ 2014$ by authors and Scientific Research Publishing Inc.

This work is licensed under the Creative Commons Attribution International License (CC BY). http://creativecommons.org/licenses/by/4.0/

(c) (i) Open Access

\begin{abstract}
MgAl LDHs intercalated with $\mathrm{CO}\left(\mathrm{NH}_{2}\right)_{2}, \mathrm{NH}_{4} \mathrm{Cl}$ and $\mathrm{NH}_{3} \cdot \mathrm{H}_{2} \mathrm{O}$ were prepared by co-precipitation and XRD, FT-IR, TGA-DTA and SEM techniques were employed for characterization. The results indicated that the layer-layer spacing of LDHs was enlarged by $0.169,0.285$ and $0.227 \AA$ with the intercalation of $\mathrm{CO}\left(\mathrm{NH}_{2}\right)_{2}, \mathrm{NH}_{4}^{+}$and $\mathrm{NH}_{3}$, separately. The effects on thermal stability and degradation behavior of synthesized $\mathrm{LDHs}$ where mole ratios of $\mathrm{Mg} / \mathrm{Al} / \mathrm{urea}=3: 1: 1, \mathrm{Mg} / \mathrm{Al} / \mathrm{NH}_{4} \mathrm{Cl}=3: 1: 1.5$ and $\mathrm{Mg} / \mathrm{Al} / \mathrm{NH}_{3} \cdot \mathrm{H}_{2} \mathrm{O}=3: 1: 0.5$ were investigated by Congo Red Method and thermogravimetric analysis (TGA) from $25^{\circ} \mathrm{C}-800^{\circ} \mathrm{C}$ under $\mathrm{N}_{2}$. The TGA and DTA results showed, by incorporating $5 \%$ MgAl-CO(NH $\left.{ }_{2}\right)_{2} \mathrm{LDH}$, the dehydrochlorination temperature of PVC composites is $12^{\circ} \mathrm{C}$ higher than MgAl- $\mathrm{NH}_{4}^{+}$and MgAl- $\mathrm{NH}_{3}$ LDHs. MgAl- $\mathrm{NH}_{3} \mathrm{LDH}$ enhances the ending temperature of the first degradation stage of PVC composites by $8^{\circ} \mathrm{C}$ compared with MgAl LDH. The LDH intercalated with $\mathrm{CO}\left(\mathrm{NH}_{2}\right)_{2}$ is proved to be an effective thermal stabilizer for PVC processing.
\end{abstract}

\section{Keywords}

Poly(vinyl chloride), Layered Double Hydroxide, Thermal Stability

\section{Introduction}

Poly(vinyl chloride) is one of the most widely used commercial thermoplastics, which has many merits such as low cost, good mechanical properties, excellent processing properties. Chlorine builds up 56.8\% of PVC, making it to be inherently flam-retardant but meanwhile thermally and photo chemically [1].

*Corresponding authors.

How to cite this paper: Xue, X.Y., Zhang, H.M. and Zhang, S.H. (2014) Preparation of MgAl LDHs Intercalated with Amines and Effect on Thermal Behavior for Poly(vinyl chloride). Advances in Materials Physics and Chemistry, 4, 258-266.

http://dx.doi.org/10.4236/ampc.2014.412028 
"Unstable structure" such as allyl chloride existed in PVC results in taking off $\mathrm{HCl}$ when it is processed, which causes the polymer degradation [2]. $\mathrm{Cl}^{-}$can be absorbed into the interlayer of LDHs (Layered Double Hydroxides, abbreviated as LDHs), which suppresses the catalysis of the free $\mathrm{HCl}$ for the PVC decomposition and improves thermal stability of PVC. Hydrotalcite is a synthetic anionic inorganic laminar compound, which is generally composed of at least two kinds of metal hydroxides [3]. As a kind of "green" inorganic materials with special properties, LDHs can be widely used in adsorption, catalysis and PVC thermal stabilizers, flame retardant, acid scavengers [4]-[10]. The general formula of the chemical composition for LDHs is:

$\left[\mathrm{M}_{1-\mathrm{x}}{ }^{2+} \mathrm{M}_{\mathrm{x}}^{3+}(\mathrm{OH})_{2}\right]\left[\mathrm{A}^{\mathrm{n}-}\right]_{\mathrm{x} / \mathrm{n}} \cdot \mathrm{mH}_{2} \mathrm{O}$, where $\mathrm{M}^{2+}$ is a divalent metal cation, $\mathrm{M}^{3+}$ is a trivalent metal cation, $\mathrm{A}^{\mathrm{n}-}$ is a interlayered $\mathrm{n}$-valent inorganic (organic) anion [11] [12]. When $\mathrm{x}$ is between 0.20 and 0.33, i.e. the molar ratio of $\mathrm{M}^{2+} / \mathrm{M}^{3+}$ ranged from 2 to 4 [13]. Great amount of crystal water and absorbed water is present in the structure of hydrotalcite and large quantity of non-bridging hydroxyl and carbonate exists in the interlayer.

In order to improve the thermal stability and compatibility of hydrotalcites for PVC, LDHs must be modified. Ammonia and amines are often used to eliminate odors resulted from the thermal stabilizers such as mercaptan tin used in PVC. Ammonium ion which is obviously alkaline or ammonium ion-containing substituent supplant can be adsorbed on the surface or intercalated between the layers of LDHs. They can strengthen the capacity of absorbing $\mathrm{Cl}^{-}$; the steric hindrance between the particles was enhanced, which prevented overlapping between the particles. Abir, S. and his coworkers studied cyanoguanidine-metal and urea-metal complex on the thermal stability for PVC and found out that urea had a thermal stability effect for PVC; urea/organotin mercaptide complex exhibited better stability than mercaptan tin [14]. Hong Zhu developed MgAl- $\mathrm{CO}_{3}^{2-}$-Cu LDHs with urea as a donor of $\mathrm{CO}_{3}^{2-}$ and studied its thermal stability and smoke suppression; they found out that $\mathrm{MgAl}-\mathrm{CO}_{3}^{2-}-\mathrm{Cu}$ LDHs had an excellent thermal stability for PVC. Xiaopeng Xu et al. investigated kinds of the stability effects of uracil derivatives for PVC and revealed the synergistic effect between $\mathrm{Zinc}^{\mathrm{St}} \mathrm{t}_{2}$ and n-monomethyl-6-aminothiouracil [15]. Conglin Wang and his coworkers reported the new synthesis routes of $\mathrm{MgAlZn}-\mathrm{CO}_{3} \mathrm{LDHs}$ with urea as donor of $\mathrm{CO}_{3}^{2-}$ [16]. Lin Yanjun and his coworkers concerned deeply about the study of $\mathrm{MgAl}-\mathrm{CO}_{3}-$ LDHs and $\mathrm{ZnAl}-\mathrm{CO}_{3}$ LDHs [17] [18].

In this research, $\mathrm{MgAl}-\mathrm{NH}_{3} \cdot \mathrm{H}_{2} \mathrm{O}, \mathrm{MgAl}-\mathrm{NH}_{4}^{+}$and $\mathrm{MgAl}-\mathrm{CO}\left(\mathrm{NH}_{2}\right)_{2} \mathrm{LDHs}$ nanoparticles with molar ratio of $\mathrm{M}^{2+} / \mathrm{M}^{3+}=3$ and different molar ratio of Al/amines were synthesized using modified homogeneous co-precipitation method. The thermal stabilizing effects on PVC were studied with Congo red test and TGA/DTA analusis. The structural evolution of LDHs was examined and the influence on improving the thermal stability of PVC was discussed.

\section{Experimental}

\subsection{Synthesis of LDHs}

Magnesium nitrate, aluminum nitrate, sodium hydroxide, anhydrous sodium carbonate, $\mathrm{CO}\left(\mathrm{NH}_{2}\right)_{2}, \mathrm{NH}_{3} \cdot \mathrm{H}_{2} \mathrm{O}$, $\mathrm{NH}_{4} \mathrm{Cl}$, di-n-octyl phthalate (DOP), all were of analytical grade, provided by the Shanghai Pharmaceutical Group Co., Ltd.; PVC resin, provided by Shanghai Chlor-Alkali Co., Ltd.

LDHs were synthesized by co-precipitation method [19]. LDHs with $\mathrm{Mg}^{2+} / \mathrm{Al}^{3+}=3$ and different molar ratio of $\mathrm{Al}^{3+} / \mathrm{CO}\left(\mathrm{NH}_{2}\right)_{2}, \mathrm{NH}_{4}^{+}$or $\mathrm{NH}_{3}$ were dissolved with deionized water as acid solution, separately. Sodium carbonate/sodium hydroxide $=1.6$ were formulated into alkaline solution with deionized water. The two solutions were simultaneously added dropwise slowly into the flask (stirring vigorously) which contained $50 \mathrm{ml}$ deionized water at $90^{\circ} \mathrm{C}$ and the $\mathrm{pH}$ is controlled at $9-10$. After the dropping, kept stirring for another $2-3 \mathrm{~h}$ with $400 \mathrm{r} / \mathrm{min}$ stirring speed. Then the reaction solution was aged at $65^{\circ} \mathrm{C}$ for $18 \mathrm{~h}$, filtered with de-ionized water to neutrality and then dried in vacuum at $80^{\circ} \mathrm{C}$ for $15 \mathrm{~h}$. The white solids obtained were ground into a fine powder.

\subsection{Characterization}

Congo Red tests were employed to examine a static thermal stability of PVC/LDHs composites with 100 phr of PVC, 5 phr of DOP, and 5 phr of synthesized LDHs. According to the standard of ISO 182/1-1990, the time of color change to $\mathrm{pH}=3$ on Congo Red paper due to the reaction with the released $\mathrm{HCl}$ was determined at $190^{\circ} \mathrm{C}$ $\pm 2^{\circ} \mathrm{C}$.

Simultaneous thermogravimetric (TGA) and differential thermal analyses (DTA) of PVC/LDHs composites were carried out on a S I I Nano TGA-DTA instrument. Analysis was done from $20^{\circ} \mathrm{C}$ to $800^{\circ} \mathrm{C}$ at a heating rate 
of $10^{\circ} \mathrm{C} \cdot \mathrm{min}^{-1}$ under nitrogen $\left(50 \mathrm{~mL} \cdot \mathrm{min}^{-1}\right)$ for thermal stability analysis.

X-ray diffraction (XRD) patterns of the LDHs were obtained with a PANalytical X Per X Per P PRO diffractometer using $\mathrm{Cu} \mathrm{K} \alpha$ radiation with $30 \mathrm{~mA}$ and $40 \mathrm{kV}$ power supply. The patterns were recorded over $2 \theta$ angles ranging from $5^{\circ}$ to $80^{\circ}, 2 \theta$ rate $40 \mathrm{~min}^{-1}$.

Infrared (IR) spectroscopy was recorded using a Nicolet AVATAR 370. Fourier Transform Infrared Spectrometer in the range $4000-400 \mathrm{~cm}^{-1}$ in tablets in air. The sample were mixed in $0.200 \mathrm{~g} \mathrm{KBr}$ (p.a.) and used to form tablets with surface of $1 \mathrm{~cm}^{2}$.

The morphologies were acquired on a S-3400N scanning electron microscope (SEM) manufactured by Japan's Hitachi company.

\section{Results and Discussion}

\subsection{Congo Red Tests}

PVC composites with $5 \mathrm{wt} \% \mathrm{MgAl}, \mathrm{MgAl}-\mathrm{CO}\left(\mathrm{NH}_{2}\right)_{2}, \mathrm{MgAl}-\mathrm{NH}_{4}^{+}$and MgAl- $\mathrm{NH}_{3}$ LDHs were prepared by melt blending and the results of Congo Red tests are as shown in Table 1. MgAl-CO(NH$\left.)_{2}\right)_{2} \mathrm{LDH}(1)$, MgAl$\mathrm{NH}_{4}^{+}$LDH (7) and MgAl- $\mathrm{NH}_{3} \mathrm{LDH}$ (10) which have the longest thermal stability time were chosen as the thermal stabilizers to PVC composites in this paper.

The influence of the LDHs on the thermal stability and dehydrochlorination process of PVC showed that the thermal stability time of neat PVC with $5 \% \mathrm{MgAl}$ LDHs is only about $18.5 \mathrm{~min}$. After incorporating $5 \mathrm{wt} \%$ MgAl-CO(NH $)_{2}\left(\mathrm{Mg}: \mathrm{Al}: \mathrm{CO}\left(\mathrm{NH}_{2}\right)_{2}=3: 1: 1\right), \mathrm{MgAl}-\mathrm{NH}_{4}^{+} \quad\left(\mathrm{Mg}: \mathrm{Al}: \mathrm{NH}_{4}^{+}=3: 1: 1.5\right)$ and $\mathrm{MgAl}-\mathrm{NH}_{3}\left(\mathrm{Mg}: \mathrm{Al}: \mathrm{NH}_{3}=\right.$ 3:1:0.5) LDHs, separately, the thermal stability time of PVC composites significantly increased to 31.5 min, 38 min and 43 min. The incorporation of $\mathrm{NH}_{3} \cdot \mathrm{H}_{2} \mathrm{O}\left(\mathrm{NH}_{4} \mathrm{OH}\right)$ into LDH platelets significantly increases the thermal stability time of PVC/LDHs composites by more than 20 min longer compared with MgAl LDH. This is because $\mathrm{NH}_{4} \mathrm{OH}$ can react with $\mathrm{HCl}$ effectively and decrease the catalytic effect of $\mathrm{HCl}$ to $\mathrm{PVC}$ degradation. The reaction process is as below:

$$
\mathrm{NH}_{4} \mathrm{OH}+\mathrm{HCl} \rightarrow \mathrm{NH}_{4} \mathrm{Cl}+\mathrm{H}_{2} \mathrm{O}
$$

According to literature [20], urea is a very weak Bronsted base ( $\mathrm{pKb}=13.8$ ), highly soluble in water, and its hydrolysis rate may be easily controlled by controlling the temperature of the reaction. Urea is easy to form ammonium cyanate and then hydrolyzes into $\left(\mathrm{NH}_{4}\right)_{2} \mathrm{CO}_{3}$ [21].

Table 1. The results of thermal stability time.

\begin{tabular}{ccc}
\hline Sample code & Molar ratio & Stability time/min \\
\hline 0 & $\mathrm{Mg} / \mathrm{Al}=3: 1$ & 18.5 \\
1 & $\mathrm{Mg} / \mathrm{Al} / \mathrm{urea}=3: 1: 1$ & 31.5 \\
3 & $\mathrm{Mg} / \mathrm{Al} / \mathrm{urea}=3: 1: 0.5$ & 26.0 \\
4 & $\mathrm{Mg} / \mathrm{Al} / \mathrm{urea}=3: 1: 1.5$ & 24.0 \\
5 & $\mathrm{Mg} / \mathrm{Al} / \mathrm{urea}=3: 1: 2$ & 25.5 \\
6 & $\mathrm{Mg} / \mathrm{Al} / \mathrm{NH}_{4} \mathrm{Cl}=3: 1: 1$ & 28.5 \\
7 & $\mathrm{Mg} / \mathrm{Al} / \mathrm{NH}_{4} \mathrm{Cl}=3: 1: 0.5$ & 30.0 \\
8 & $\mathrm{Mg} / \mathrm{Al} / \mathrm{NH}_{4} \mathrm{Cl}=3: 1: 1.5$ & 38.0 \\
9 & $\mathrm{Mg} / \mathrm{Al} / \mathrm{NH}_{4} \mathrm{Cl}=3: 1: 2$ & 33.0 \\
10 & $\mathrm{Mg} / \mathrm{Al} / \mathrm{ammonia}=3: 1: 1$ & 30.0 \\
11 & $\mathrm{Mg} / \mathrm{Al} / \mathrm{ammonia}=3: 1: 0.5$ & 43.0 \\
12 & $\mathrm{Mg} / \mathrm{Al} / \mathrm{ammonia}=3: 1: 1.5$ & 39.0 \\
\hline
\end{tabular}




$$
\begin{gathered}
\mathrm{CO}\left(\mathrm{NH}_{2}\right)_{2} \rightarrow\left(\mathrm{NH}_{4}\right)_{2} \mathrm{CON} \\
\mathrm{NH}_{4} \mathrm{CNO}+2 \mathrm{H}_{2} \mathrm{O} \rightarrow\left(\mathrm{NH}_{4}\right)_{2} \mathrm{CO}_{3}
\end{gathered}
$$

MgAl-CO( $\left(\mathrm{NH}_{2}\right)_{2} \mathrm{LDH}$ can improve the thermal stability by increasing the carbonate ion concentration in the interlayer of LDHs, which will escape from the interlayer over $200^{\circ} \mathrm{C}$ and react with $\mathrm{HCl}$. $\mathrm{NH}_{4}^{+}$will locate on the layer of $\mathrm{LDH}$. However, When $\mathrm{NH}_{4} \mathrm{Cl}$ is inserted in the $\mathrm{LDHs}, \mathrm{NH}_{4}^{+}$will locate on the layers and $\mathrm{Cl}^{-}$is in the interlayers. $\mathrm{NH}_{4}^{+}$can react with $\mathrm{HCl}$ as well.

\subsection{Powder X-Ray Diffraction}

XRD spectra of the samples are shown in Figure 1.

Figure 1 shows the MgAl-CO(NH$)_{2}, \mathrm{MgAl}-\mathrm{NH}_{4}^{+}$and $\mathrm{MgAl}-\mathrm{NH}_{3} \mathrm{LDHs}$ have low and stable baseline in XRD spectra with sharp absorption peaks for the (003), (006), (110) and (113) planes and broad asymmetric peaks for the (102), (105) and (108) planes which are characteristic of MgAl LDH structure [21]. The shapes of diffraction peaks of MgAl LDH and MgAl- $\mathrm{NH}_{3} \mathrm{LDH}$ are sharp and narrow as well as symmetrical, which demonstrate the crystallization of these two LDHs are complete and the crystal phases are single. The diffraction peaks of MgAl- $\mathrm{NH}_{4}^{+}$and MgAl-CO(NH$)_{2} \mathrm{LDH}$ became wider and lower, which means their crystallizations are decrease. The Debye-Scherrer formula $\left(\mathrm{t}=0.9 \lambda / \beta \cos \theta_{\mathrm{B}}\right)$, where $\lambda$ is the wavelength of the radiation used, $\beta$ is the integral breadth of the peak and $\theta_{\mathrm{B}}$ is the Bragg diffraction angle, was employed to calculate the particle sizes of the samples according to the parameters of (003) and (110) planes [22], which are shown in Table 2.

The results show that the particle sizes of $\mathrm{MgAl} \mathrm{LDHs}$ became smaller after being intercalated with $\mathrm{CO}\left(\mathrm{NH}_{2}\right)_{2}$, $\mathrm{NH}_{4} \mathrm{Cl}$ and $\mathrm{NH}_{3}$, that of MgAl-CO(NH$)_{2}$ is the smallest. This is due to the molecular weight and particles' radius of urea is larger than $\mathrm{NH}_{4} \mathrm{Cl}$ and ammonia, with the increase of the molecular weight and particles' radius, intercalation effect becomes worse. At the same time, the crystallines fall down.

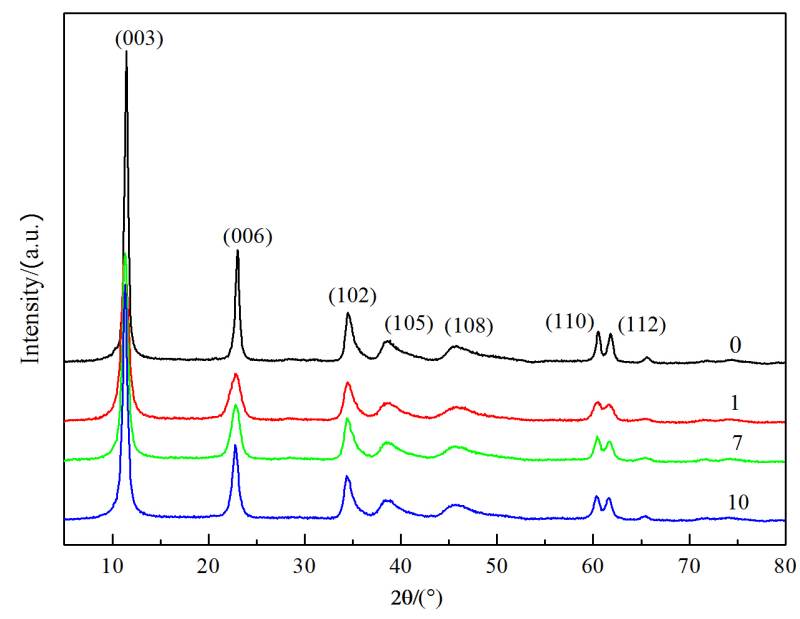

Figure 1. XRD patterns. 0: $\mathrm{MgAl} \mathrm{LDH} ; 1: \mathrm{MgAl}-\mathrm{CO}\left(\mathrm{NH}_{2}\right)_{2}$ LDH; 7: MgAl- $\mathrm{NH}_{4}^{+}$LDH; 10: MgAl- $\mathrm{NH}_{3} \mathrm{LDH}$.

\begin{tabular}{|c|c|c|c|c|}
\hline \multirow{2}{*}{ LDHs samples } & \multicolumn{4}{|c|}{ The first mass loss stage } \\
\hline & $\begin{array}{l}\text { Temperatures } \\
\text { at the beginning }\left({ }^{\circ} \mathrm{C}\right)\end{array}$ & $\begin{array}{c}\text { Temperatures } \\
\text { at the max rate }\left({ }^{\circ} \mathrm{C}\right)\end{array}$ & $\begin{array}{l}\text { Temperatures } \\
\text { at the end }\left({ }^{\circ} \mathrm{C}\right)\end{array}$ & $\begin{array}{c}\text { Mass loss } \\
\text { rate (\%) }\end{array}$ \\
\hline Mg-Al & 259.30 & 310.69 & 368.02 & 57.57 \\
\hline Mg-Al-CO(NH$\left.)_{2}\right)_{2}$ & 278.59 & 313.41 & 369.72 & 56.52 \\
\hline Mg-Al- $\mathrm{NH}_{4}^{+}$ & 266.14 & 313.65 & 367.41 & 55.14 \\
\hline $\mathrm{Mg}-\mathrm{Al}-\mathrm{NH}_{3}$ & 266.63 & 315.61 & 374.86 & 54.71 \\
\hline
\end{tabular}

Table 2. The mass loss rates and the decomposition temperatures. 


\subsection{Infrared Spectroscopy}

The information about interlayer anions, crystalline water and the lattice oxygen vibrations in the layer of LDHs can be obtained from the FT-IR analysis. IR spectra of the samples were shown in Figure 2.

FT-IR spectra display the characteristic bands for $\mathrm{OH}$ and $\mathrm{CO}$ bonds that are abundantly present in MgAlLDH [23]. A broad band is visible (3436 - $3487 \mathrm{~cm}^{-1}$ ) that may be attributed to stretching vibrations of the hydroxyl ions and hydroxyl groups of the intercalated water. The weak band at $1620 \mathrm{~cm}^{-1}$ is due to the bending mode of water molecules. Compared to $\mathrm{MgAl} \mathrm{LDH}$, that of $\mathrm{MgAl}-\mathrm{CO}\left(\mathrm{NH}_{2}\right)_{2}, \mathrm{MgAl}-\mathrm{NH}_{4}^{+}$and $\mathrm{MgAl}-\mathrm{NH}_{3}$ LDH becomes wider obviously, which results from the stretching vibrations of amino group bonded with hydroxyl and carbonyl. Acromion arose at $2750-3050 \mathrm{~cm}^{-1}$, which can be assigned to $\mathrm{H}_{2} \mathrm{O}-\mathrm{CO}_{3}^{2-}$ bridge vibration mode formed by hydrogen bonds between water molecules and interlaminar $\mathrm{CO}_{3}^{2-}$ group. Weak peak at $2250-2450 \mathrm{~cm}^{-1}$ belongs to the stretching vibration of $\mathrm{NH}$ bond. The peak at $1360-1380 \mathrm{~cm}^{-1}$ is caused by the asymmetric stretching vibration of C-O bond of $\mathrm{CO}_{3}^{2-}$ group, compared with $\mathrm{CO}_{3}^{2-}$ group in free state (1415 $\mathrm{cm}^{-1}$ ), this peak obviously shift to lower wavenumber, which indicates $\mathrm{CO}_{3}^{2-}$ inserted between layers not truly free ions and have strong hydrogen bonds with interlaminar water molecules. The peak in $\mathrm{MgAl}-\mathrm{CO}\left(\mathrm{NH}_{2}\right)_{2}$ is a little stronger due to the greater concentration of carbonate. While other absorption bands below $800 \mathrm{~cm}^{-1}$ are associated with the stretching and bending modes of metal-oxygen bonds [23]. The results proved $\mathrm{CO}\left(\mathrm{NH}_{2}\right)_{2}$, $\mathrm{NH}_{4}^{+}$and $\mathrm{NH}_{3}$ inserted into the $\mathrm{LDH}$ layer successfully.

\subsection{SEM Analysis}

The particle morphologies of all of the synthesized materials are investigated by means of SEM, which are shown in Figure 3. Pure MgAl LDH shows a clear and structured crystalline perfection (Figure 4(0)) and the lamellae crystals distribute on the particles. $\mathrm{MgAl}-\mathrm{CO}\left(\mathrm{NH}_{2}\right)$ and $\mathrm{MgAl}-\mathrm{NH}_{3} \mathrm{LDHs}$ exhibit layer structures and the crystals dispersed on the surface of the particles, but the crystal sizes are smaller and agglomerate into a big block (Figure 4(1) and Figure 4(10)). Sample 7 doesn't have obvious crystal structures and the slice groups tend to move together. It can clearly be seen that intercalating ammonium and urea weaken the grain dispersion and the particle sizes became larger, the layer spacing became larger, the surface area becomes larger and had the tendency to agglomerate. The SEM analysis further validated the effect of ammonium and urea to the crystal structures of LDHs.

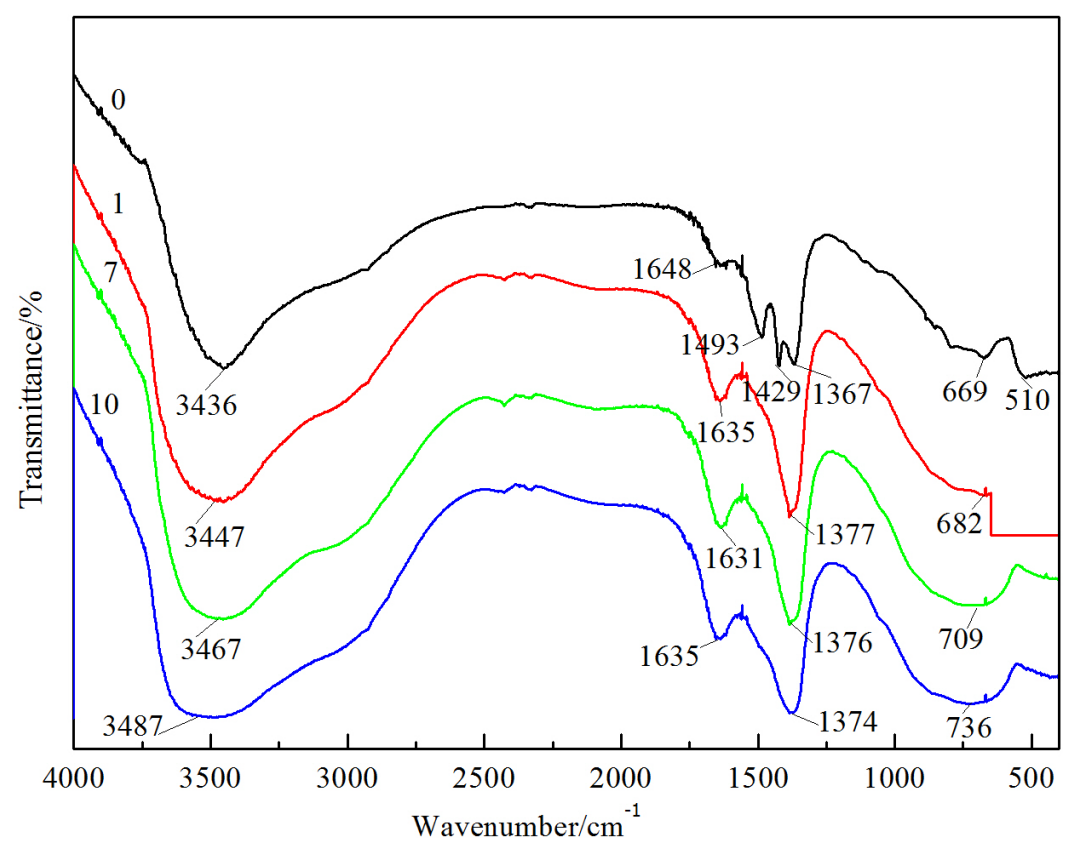

Figure 2. IR spectra. 0: MgAl LDH; 1: $\mathrm{MgAl}-\mathrm{CO}\left(\mathrm{NH}_{2}\right)_{2} \mathrm{LDH} ; 7: \mathrm{MgAl}-\mathrm{NH}_{4}^{+} \mathrm{LDH} ; 10$ : MgAl- $\mathrm{NH}_{3} \mathrm{LDH}$. 

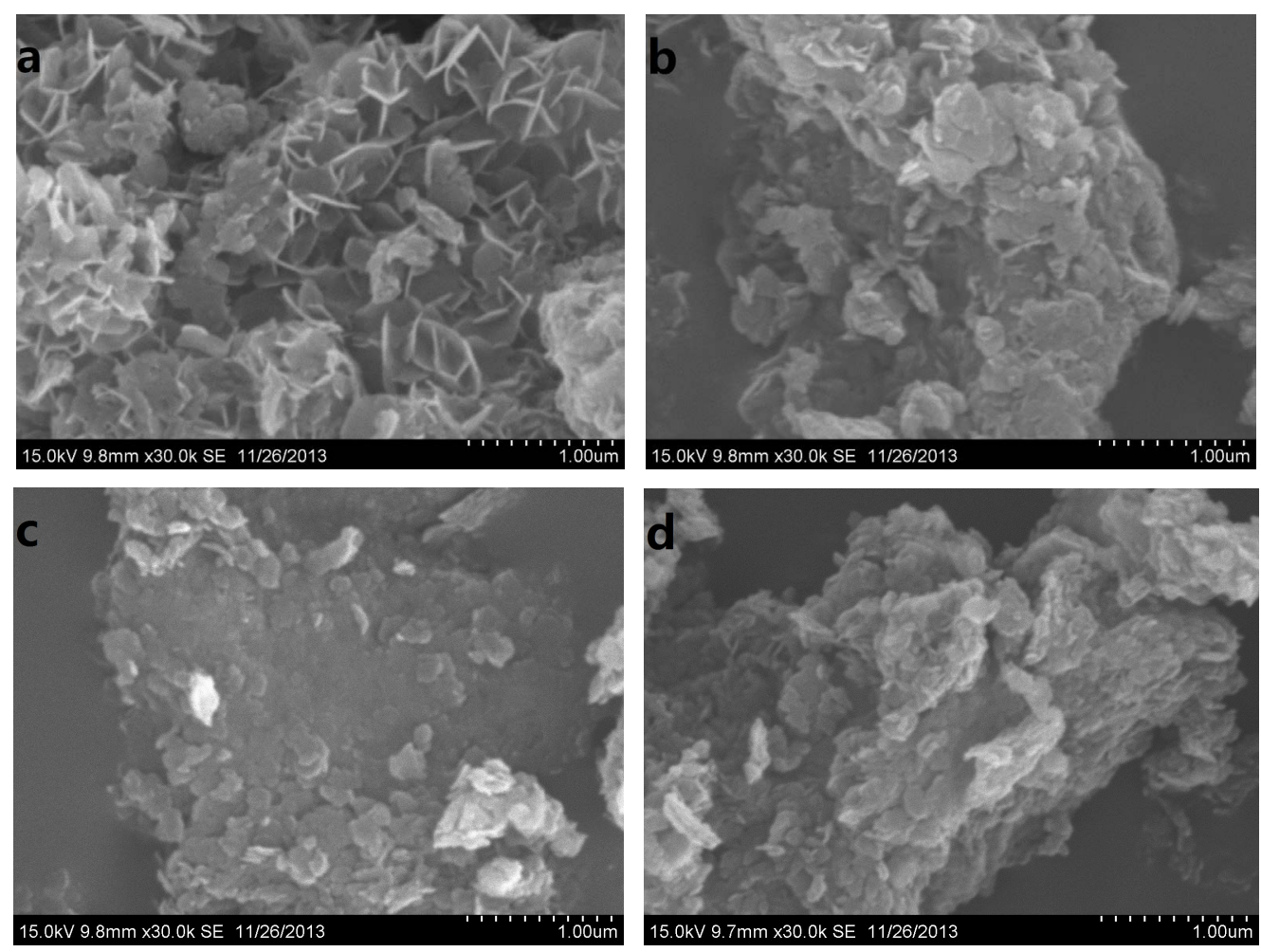

Figure 3. SEM images. (a) MgAl LDH; (b) MgAl-CO(NH$)_{2} \mathrm{LDH}$; (c) MgAl- $\mathrm{NH}_{4}^{+} \quad \mathrm{LDH}$; (d) MgAl-NH $\mathrm{LDH}_{3}$

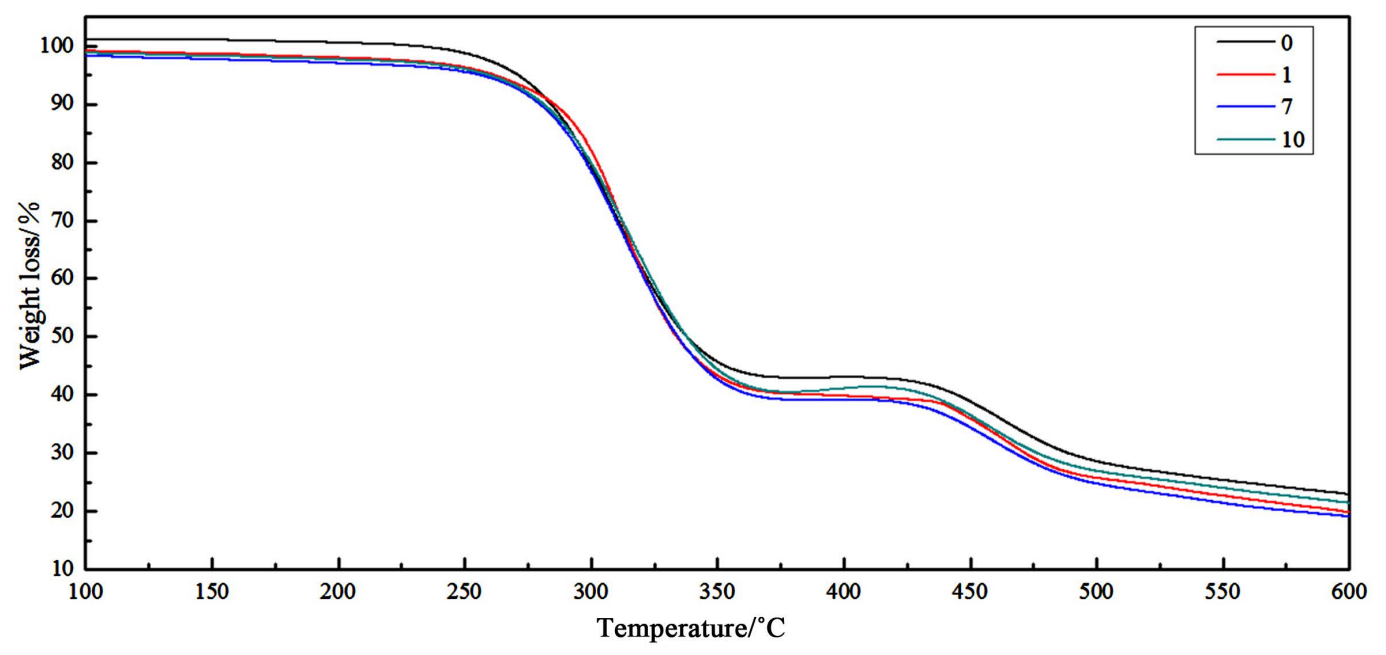

Figure 4. TGA curves. 0: MgAl LDH; 1 : MgAl-CO(NH$)_{2}$ LDH; 7: MgAl- $\mathrm{NH}_{4}^{+} \quad$ LDH; 10: MgAl-NH $\mathrm{LDH}_{3}$

\subsection{Thermal Stability Analysis}

TGA and DTA curves in $\mathrm{N}_{2}$ for PVC composites with four kinds of LDHs are shown in Figure 4 and Figure 5 and the analysis data were listed in Table 2. The degradation of PVC resin usually consists of two steps. The initial step is the dehydrochlorination which includes autocatalysis process by releasing $\mathrm{HCl}$ and the formation of conjugated polyene sequences. The second step is the decomposition of polyene back ones and formation of residual chars [24]. The TG curves may be divided into two well-differentiated main regions. In the first one, ranging from $80^{\circ} \mathrm{C}$ to $400^{\circ} \mathrm{C}$, there is a broad endothermic peak in DTA related to the dehydrochlorination and the formation of conjugated polyene sequences. The released $\mathrm{HCl}$ will catalytically speed up the degradation of 


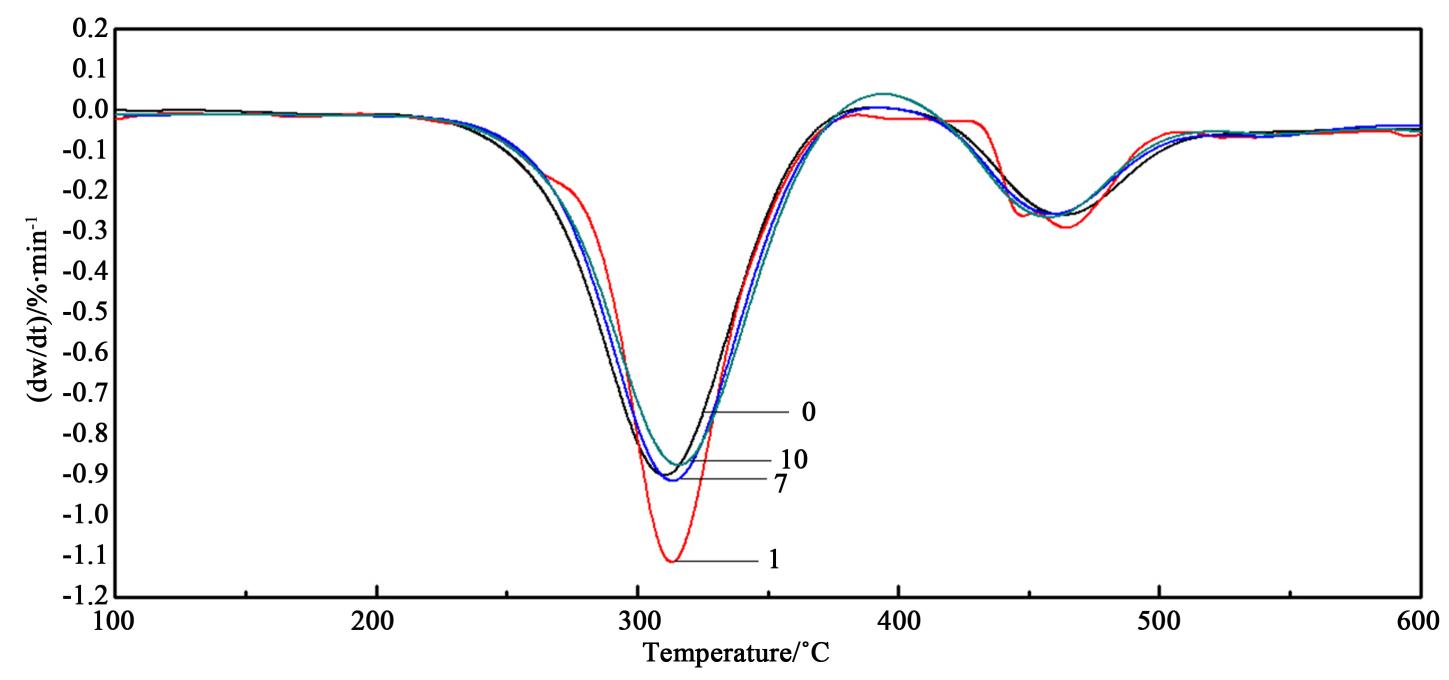

Figure 5. DTG curves. 0: MgAl LDH; 1: MgAl-CO(NH $)_{2}$ LDH; 7: MgAl- $\mathrm{NH}_{4}^{+} \quad$ LDH; 10: MgAl-NH $\mathrm{LDH}$

PVC. The hydroxyl groups, as well as the $\mathrm{CO}_{3}^{2-}$ and other interlayer anions such as ammonia removal from the in the brucite-like layers of hydrotalcites in this temperature range can react with hydrochlorination and restrain PVC degradation further effectively [24]. The second region ranging over $400^{\circ} \mathrm{C}$, another small endothermic peak attribute to decomposition of polyene backones and formation of residual chars. The first step can be used to describe the degradation of the processing and use for PVC.

As for PVC/ MgAl LDHs, the first stage of weight loss begins as early as $259.30^{\circ} \mathrm{C}$ and reaches the maximum rate at $310.69^{\circ} \mathrm{C}$, and then ends at $368.02^{\circ} \mathrm{C}$. While the initial degradation temperatures of $\mathrm{PVC} / \mathrm{MgAl}-\mathrm{CO}\left(\mathrm{NH}_{2}\right)_{2}$, $\mathrm{MgAl}-\mathrm{NH}_{4}^{+}$and $\mathrm{MgAl}-\mathrm{NH}_{3} \mathrm{LDHs}$ are $278.59^{\circ} \mathrm{C}, 266.14^{\circ} \mathrm{C}$ and $266.63^{\circ} \mathrm{C}$, separately. The results prove that the addition of MgAl-CO $\left(\mathrm{NH}_{2}\right)_{2} \mathrm{LDH}$ increases the temperature by $20^{\circ} \mathrm{C}$, which is about $7^{\circ} \mathrm{C}$ by $\mathrm{MgAl}-\mathrm{NH}_{4}^{+}$and MgAl- $\mathrm{NH}_{3}$ LDHs. At the beginning of PVC degradation, the catalytic action of $\mathrm{HCl}$ released from PVC chain is the key. The best thermal stability of MgAl-CO(NH$\left.)_{2}\right)_{2} \mathrm{LDH}$ may be assigned to the increase of carbonate ion concentration in the interlayers of LDHs which can react more $\mathrm{HCl}$. The increase of thermal stability resulted from adding MgAl- $\mathrm{NH}_{4}^{+}$and MgAl-NH $\mathrm{N}_{3} \mathrm{LDHs}$ can be attributed to $\mathrm{NH}_{4}^{+}$and $\mathrm{NH}_{3}$ can also react with $\mathrm{Cl}^{-}$ bonded in the interlayers through anion exchange except $\mathrm{OH}^{-}$and $\mathrm{CO}_{3}^{2-}$. As for PVC, thermal stabilizers play an important role during the processing ranging from $100^{\circ} \mathrm{C}$ to $250^{\circ} \mathrm{C}$, therefore, we can conclude MgAl$\mathrm{CO}\left(\mathrm{NH}_{2}\right)_{2}$ is a kind of effective thermal stabilizers for PVC processing.

With the temperature rises up over $300^{\circ} \mathrm{C}$, PVC composites reach the maximum degradation rate and small molecules and ions in the interlayer escape continuously and polyene backbones formed. Chloride ions begin to react with metal ions into lewis acid, which act as reductive crosslinking agent and suppress benzene production. It can be seen from Table 2, at the end of the first step, the weight loss of PVC/MgAl- $\mathrm{NH}_{3} \mathrm{LDH}$ composite ends at $374.86^{\circ} \mathrm{C}$, which is higher than the other three composites by $5^{\circ} \mathrm{C}-7^{\circ} \mathrm{C}$. It is because its molecule weight is smaller, the concentration of magnesium and aluminum ions which act as reductive crosslinking agent are higher in contrast, so more crosslinking structures can be formed to suppress benzene production. This result is consistent with that of Congo Red tests and indicated the better long term thermal stability of $\mathrm{MgAl}-\mathrm{NH}_{3} \mathrm{LDH}$.

\section{Conclusions}

MgAl LDHs intercalated with $\mathrm{CO}\left(\mathrm{NH}_{2}\right)_{2}, \quad \mathrm{NH}_{4}^{+}$and $\mathrm{NH}_{3}$ have been prepared by co-precipitation method. XRD and FT-IR analysis proved that the synthesized LDHs have the characterized diffraction peaks and functional groups, while their crystalline declined. WAXS studies have enabled a detailed description of the layer-layer spacing to increase $0.169,0.285$ and $0.227 \AA$. The change of the interlamellar distance is ascribed to the $\mathrm{CO}_{3}^{2-}$, $\mathrm{NH}_{4}^{+}$and $\mathrm{NH}_{3}$ intercalating into the MgAl-CO $\left(\mathrm{NH}_{2}\right)_{2} \mathrm{LDH}, \mathrm{MgAl}-\mathrm{NH}_{4}^{+} \mathrm{LDH}$ and MgAl- $\mathrm{NH}_{3} \mathrm{LDH}$ through the anion exchange.

The addition of MgAl-CO(NH$\left.)_{2}\right)_{2}$ LDH into PVC matrix significantly increases the dehydrochlorination tem- 
perature, and the addition of $\mathrm{MgAl}-\mathrm{NH}_{3}$ increases the long term thermal stability for PVC. When compared with $\mathrm{MgAl} \mathrm{LDH}, \mathrm{MgAl}-\mathrm{CO}\left(\mathrm{NH}_{2}\right)_{2} \mathrm{LDH}$ enhances the initial degradation temperature of PVC composites by about $20^{\circ} \mathrm{C}$, while $\mathrm{MgAl}-\mathrm{NH}_{3} \mathrm{LDH}$ enhances the temperature of $5^{\circ} \mathrm{C}-7^{\circ} \mathrm{C}$ at the end of the first degradation stage.

These results confirm that MgAl-CO(NH$)_{2}$ LDH can restrain PVC degradation effectively during its processing, and MgAl- $\mathrm{NH}_{3} \mathrm{LDH}$ is a good kind of long term thermal stabilizer.

\section{Acknowledgements}

We acknowledge the financial support received from Shanghai municipal education commission with "Twelfth Five” scientific connotation construction project (number: nhky-2012-05), Foreign visiting scholar fellowship program (B-8938-12-0406). The author gratefully thanks beamline 7.3.3 and 8.0.1 at Advanced Light Source of Lawrence Berkeley National Lab, supported by the Director of the Office of Science, Office of Basic Energy Sciences, of the U.S. Department of Energy under Contract No. De-AC02-05CH11231.

\section{References}

[1] Zhu, H., Wang, W.S. and Liu, T.X. (2011) Effects of Copper-Containing Layered Double Hydrotalcite on Thermal and Smoke Behavior of Poly(vinyl chloride). Journal of Applied Polymer Science, 122, 273-281. http://dx.doi.org/10.1002/app.34027

[2] Dietrich, B. (2002) Design of Anion Receptors: Applications. Pure and Applied Chemistry, 85, 1457-1464.

[3] Cavani, F., Trifiro, F. and Vaccari, A. (1991) Hydrotalcite-Type Anionic Clays Preparation, Properties and Applications. Catalysis Today, 11, 173-301. http://dx.doi.org/10.1016/0920-5861(91)80068-K

[4] Niu, X.N., Zhao, Y. and Zhu, H.T. (2010) Mg-Al-Fe Hydrotalcite Its Calcined Product Research on Reactive Red X-3B Decolorization Performance. Water Treatment Technology, 36, 35-40.

[5] Goh, K.-H., Lim, T.-T. and Dung, Z.L. (2008) Application of Layered Double Hydroxidesfor Removal of Oxyanions: A Review. Water Research, 42, 1343-1368.

[6] Li, K.R., Gu, X.Q., Hao, D.B., et al. (2010) Synthesis, Characterization and Catalytic Acetone Hydrotalcite Condensation Performance. Molecular Catalysis, 4, 309-314.

[7] Wu, N. (2010) Hydrotalcite Compound Applications in Catalysis Field. Industrial Catalysis, 18, 28-31.

[8] Liu, J., Chen, G.M. and Yang, J.P. (2008) Preparation and Characterization of Poly(vinyl chloride)/Layered Double Hydroxide Nano-Composites with Enhanced Thermal Stability. Polymer, 49, 3923-3927. http://dx.doi.org/10.1016/j.polymer.2008.07.014

[9] Lin, Y.J., Wang, J.R., Evans, D.G., et al. (2006) Layered and Intercalated Hydrotalcite-Like Materials as Thermal Stabilizers in PVC Resin. Journal of Physics and Chemistry of Solids, 67, 998-1001.

[10] Yan, H.B., Li, M., Liu, Q.F., et al. (2009) Hydrotalcite/Ca-Zn Composite Heat Stabilizer for PVC Heat Stability. Polymer Materials Science and Engineering, 25, 75-77.

[11] Nyambo, C., Chen, D., Su, S.P. and Wilkie, C.A. (2009) Does Organic Modification of Layered Double Hydroxides Improve the Fire Performance of PMMA. Polymer Degradation and Stability, 94, 1298-1306. http://dx.doi.org/10.1016/j.polymdegradstab.2009.03.023

[12] Yang, Z.H., Chi, W.W., et al. (2008) Synthesis and Application of Mg-Al-Ca Ternary Hydrotalcite in PVC. Plastics Additives, 2008, 18-21.

[13] Li, L., Mo, D. and Luo, Q.S. (2004) Reconstruction and Characterization of Zn, Al Hydrotalcite Like Compound. Chinese Journal of Inorganic Chemistry, 20, 256-260.

[14] Abdel-Naby, A.S., Al-Ghamdi, R.F. and Al-Ghamdi, A.A. (2010) Effect of Cyanoguanidine-Metal and Urea-Metal Complexes on the Thermal Degradation of Poly(vinyl chloride). Journal of Vinyl and Additive Technology, 16, 15-22. http://dx.doi.org/10.1002/vnl.20225

[15] Xu, X.P., Chen, S., Tang, W., Qu, Y.J. and Wang, X. (2013) Synthesis and Application of Uracil Derivatives as Novel Thermal Stabilizers for Rigid Poly(vinyl chloride). Polymer Degradation and Stability, 98, 659-665. http://dx.doi.org/10.1016/j.polymdegradstab.2012.11.008

[16] Wang, G.L., Yang, M., Li, Z.W., Lin, K.F., Jin, Q., Xing, C.J., Hu, Z.D. and Wang, D. (2013) Synthesis and Characterization of Zn-Doped MgAl-Layered Double Hydroxide Nanoparticles as PVC Heat Stabilizer. Journal of Nanoparticle Research, 15, 1882-1890. http://dx.doi.org/10.1007/s11051-013-1882-0

[17] Lin, Y.J., Li, D.Q., Evans, D.G. and Duan, X. (2005) Modulating Effect of Mg-Al-CO 3 Layered Double Hydroxides on the Thermal Stability of PVC Resin. Polymer Degradation and Stability, 88, 286-293. 
http://dx.doi.org/10.1016/j.polymdegradstab.2004.11.007

[18] Lin, Y.J., Wang, J.R., Evans, D.G. and Li, D.Q. (2006) Layered and Intercalated Hydrotalcite-Like Materials as Thermal Stabilizers in PVC Resin. Journal of Physics and Chemistry of Solids, 67, 998-1001. http://dx.doi.org/10.1016/j.jpcs.2006.01.016

[19] Ren, L.L., He, J. and Duan, X. (2001) Intercalation Assembled Anionic Pillared Materials. Chemical Bulletin, 64, 686-691.

[20] Costantino, U., Marmottini, F., Nocchetti, M. and Vivani, R. (1998) New Synthetic Routes to Hydrotalcite-Like Compounds-Characterization and Properties of the Obtained Materials. European Journal of Inorganic Chemistry, 10, 1439-1446. http://dx.doi.org/10.1002/(SICI)1099-0682(199810)1998:10<1439::AID-EJIC1439>3.0.CO;2-1

[21] Kannan, S. and Swamy, C.S. (1992) Synthesis and Physicochemical Characterization of Cobalt Aluminum Hydrotalcite. Journal of Materials Science Letters, 11, 1585-1587.

[22] Xie, X.M., Yan, K., Hu, Q.X., Song, J.L. and Wang, Z.Z. (2008) Preparation and Catalytic Application of CopperContaining Hydrotalcite-Like Compounds. Chinese Journal of Inorganic Chemistry, 24, 32-36.

[23] Purmova, J., Pauwels, K.F.D., van Zoelen, W., Vorenkamp, E.J. and Schouten, A.J. (2005) New Insight into the Formation of Structural Defects in Poly(vinyl chloride). Macromolecules, 38, 6352-6366. http://dx.doi.org/10.1021/ma050035p

[24] Yurco, M., Bagnasco, G., Costantino, U., Marmottini, F., Montanari, T., Ramis, G. and Busca, G. (2004) Production of Hydrogen from Oxidative Steam Reforming of Methanol: I. Preparation and Characterization of $\mathrm{Cu} / \mathrm{ZnO} / \mathrm{Al}_{2} \mathrm{O}_{3}$ Catalysts from a Hydrotalcite-Like LDH Precursor. Journal of Catalysis, 228, 43-55.

http://dx.doi.org/10.1016/S0021-9517(04)00412-9 
Scientific Research Publishing (SCIRP) is one of the largest Open Access journal publishers. It is currently publishing more than 200 open access, online, peer-reviewed journals covering a wide range of academic disciplines. SCIRP serves the worldwide academic communities and contributes to the progress and application of science with its publication.

Other selected journals from SCIRP are listed as below. Submit your manuscript to us via either submit@scirp.org or Online Submission Portal.
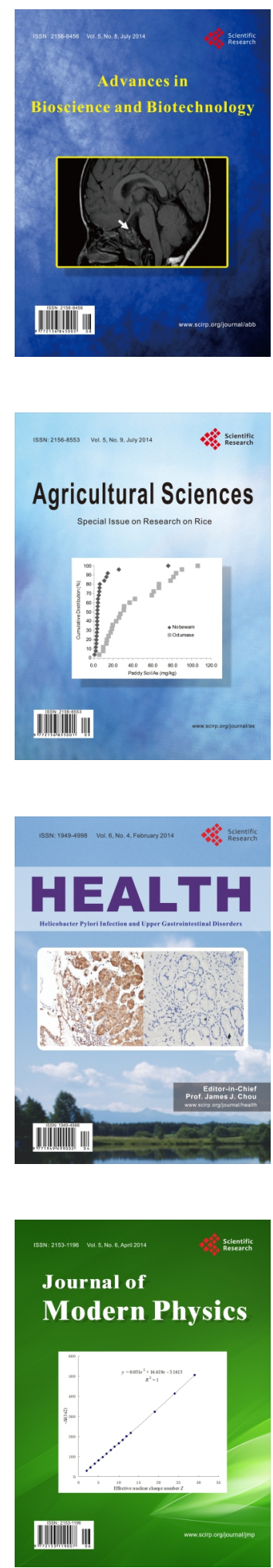
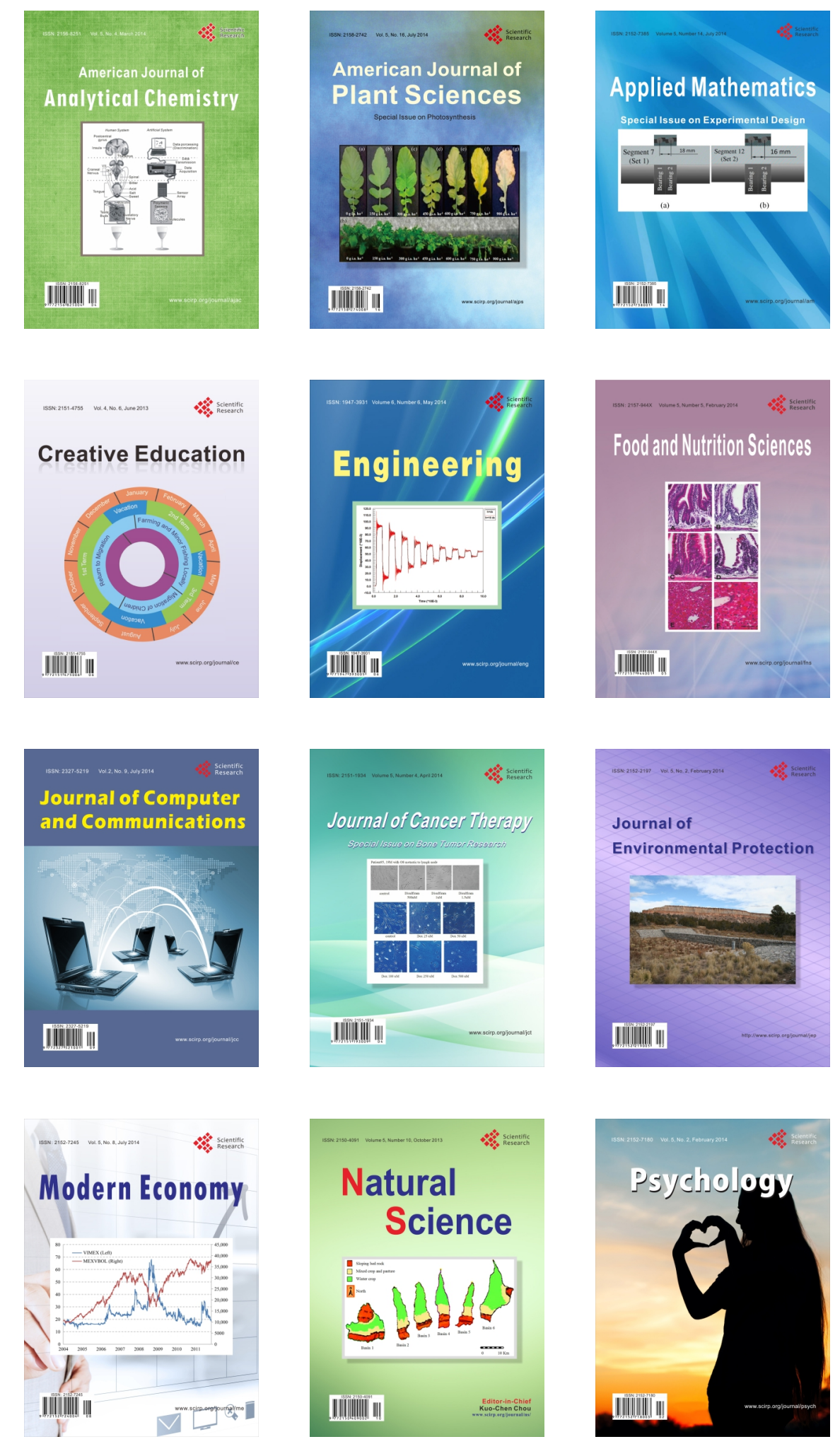